\title{
Effectiveness of human, camel, bovine and sheep lactoferrin on the hepatitis $C$ virus cellular infectivity: comparison study
}

\author{
Esmail M EL-Fakharany ${ }^{1}$, Lourdes Sánchez ${ }^{2}$, Hussein A Al-Mehdar ${ }^{3}$ and Elrashdy M Redwan ${ }^{1,3^{*}}$
}

\begin{abstract}
Purpose: The prevalence of HCV infection has increased during recent years and the incidence reach 3\% of the world's population, and in some countries like Egypt, may around 20\%. The developments of effective and preventive agents are critical to control the current public health burden imposed by HCV infection. Lactoferrin in general and camel lactoferrin specifically has been shown to have a compatitive anti-viral activity against hepatitis $C$ virus (HCV). The purpose of this study was to examine and compare the anti-infectivity of native human, camel, bovine and sheep lactoferrin on continuous of HCV infection in HepG2 cells.

Material and methods: Used Lfs were purified by Mono S 5/50 GL column and Superdex 200 5/150 column. The purified Lfs were evaluated in two ways; 1. the pre-infected cells were treated with the Lfs to inhibit intracellular replication at different concentrations and time intervals, 2. Lfs were directly incubated with the virus molecules then used to cells infection. The antiviral activity of the Lfs were determined using three techniques; 1. RT-nested $P C R$, 2. Real-time PCR and 3. Flowcytometric.
\end{abstract}

Results: Human, camel, bovine and sheep lactoferrin could prevent the HCV entry into HepG2 cells by direct interaction with the virus instead of causing significant changes in the target cells. They were also able to inhibit virus amplification in HCV infected HepG2 cells. The highest anti-infectivity was demonstrated by the camel lactoferrin.

Conclusion: CLf has inhibitory effect on HCV (genotype 4a) higher than human, bovine and sheep lactoferrin.

Keywords: Comparison, Different lactoferrin, Hepatitis C virus, Anti-infectivity

\section{Background}

The hepatitis $\mathrm{C}$ virus (HCV) is a major health problem in the world and a leading cause of chronic liver disease [1] and with an estimated about 180 million people is infected worldwide. HCV is currently the most significant public health problem in Egypt with an infection prevalence of up to $20 \%$, this is ten times greater than any other country in the world and the highest prevalence of $\mathrm{HCV}$ genotype 4 , which is responsible for $90 \%$ of infections, with a predominance of subtype 4a (55\%) [2-4]. Studies suggest that

\footnotetext{
* Correspondence: redwan1961@yahoo.com

'Therapeutic and Protective Protein Laboratory, Protein Research Department, Genetic Engineering and Biotechnology Research Institute, City for Scientific Research and Technology Applications, New Borg EL-Arab, Alexandria 21394, Egypt

${ }^{3}$ Biological Sciences Department, Faculty of Science, King Abdulaziz University, P.O. Box 80203, Jeddah 21589, Kingdom of Saudi Arabia Full list of author information is available at the end of the article
}

mortality related to $\mathrm{HCV}$ infection will increase over in the next two decades [5]. A protective vaccine against $\mathrm{HCV}$ does not exist till now, and current standard treatment for chronic HCV infection is interferon $\alpha$ alone or in combination with ribavirin. This treatment of $\mathrm{HCV}$ is costly, requires more time (12-72 weeks) to complete, and has serious adverse effects of ribavirin is hemolytic anemia that may require dose reduction, low efficiency and discontinuation of treatment. The developing new treatment against $\mathrm{HCV}$ has been hampered by difficulties in replicating the virus in cell culture and the lack of suitable animal models.

Lactoferrin (Lf) is an $80 \mathrm{kDa}$ multifunctional glycoprotein belonging to the transferrin family. Lf is primarily present in milk, and is also found in other biological fluids, such as saliva, tears, bile and pancreatic juice [6]. It has been widely documented that Lf displays antimicrobial

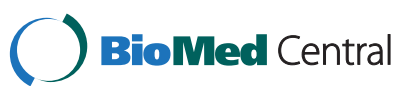


activity against many different pathogenic agents. This activity was attributed to its ability, to bind iron with a high affinity and unlike transferrin, retain its bound iron under acidic conditions. Also Lf is considered to be a part of the innate immune system and takes part in specific immune reactions, but in an indirect way [7]. The antiviral activity of Lf is directed against a broad spectrum of viruses, including both RNA- and DNA-viruses, enveloped as well as naked viruses. Lf saturated with iron ions has been shown to exhibit antiviral activity against HSV-1 and HSV-2 [8,9]. Lf also exhibit antiviral properties against HCV. Ikeda et al. [10] have shown that Lf is able to prevent the infection of $\mathrm{HCV}$ in the cultured human hepatocytes cell line $\mathrm{PH} 5 \mathrm{CH} 8$. Since pre-incubation of Lf and $\mathrm{HCV}$ was required to prevent infection of the cells it was hypothesized that the inhibition happens through a direct interaction between the virus and Lf. This idea is supported by the fact that pre-incubation of the $\mathrm{PH} 5 \mathrm{CH} 8$ cells with Lf had no inhibitory effect on $\mathrm{HCV}$, indicating that the antiviral activity of Lf against $\mathrm{HCV}$ was not due to the interaction of Lf with the cells.

Bovine and human Lfs are able to bind to the HCV envelope proteins E1 and E2 [11]. This binding inhibits any possible interaction of the virus with its cellular receptors. In all cases studied, it appears that Lf exerts its antiviral activity at an early phase in the infection process. Similar results have recently been reported for camel lactoferrin (cLf), demonstrating complete inhibition of virus entry when cLf and HCV were preincubated together, while Lf pre-incubation with human leukocytes [12], HepG2 cells [13] and Huh7.5 cells [14,15] prior to HCV infection had no effect on viral entry. Both full length of native and recombinant clf were shown similar results [14]. The enzymatic prepared of native $\mathrm{N}$ - lobe, C-lobe and recombinant $\mathrm{N}$ lobe has been shown a similar effect against HCV cellular infectivity [14]. Several viral pathogens has been shown to use host cell surface $\mathrm{HS}$ as an attachment receptor during the infection process and Lf also binds HS [16]. The results have shown that HS at the cell surface is important for Lf to exert antiviral activity $[17,18]$. The objective of this study was to examine and comparison the potential inhibitory effects of human, camel, bovine and sheep lactoferrin on HCV entry and amplification in HepG2 cells.

\section{Results}

\section{Purification of native Lfs}

Human, Camel, Bovine and Sheep lactoferrins were isolated and purified in two steps with cation exchange resin (Mono S 5/50 GL column) and gel filtration chromatography (Superdex 200 5/150 column). The skimmed milk by was loaded to Mono S 5/50 GL column and the Lfs were eluted at a salt strength of $0.0-1.0 \mathrm{M} \mathrm{NaCl}$. The peak containing Lf was concentrated and applied into Superdex $2005 / 150$ column. Only one band was visualized on $12 \%$
SDS-PAGE of the protein for all Lfs. The electrophoretic analysis of the protein eluted revealed that the presented a single protein band corresponding to about $80 \mathrm{KDa}$ (Figure 1) without clear differences in the molecular weight of all lactoferrins.

\section{Cytotoxic effect of hLf, cLf, bLf and sLf}

To exclude the possibility that the elimination of the HCV was caused by the reduced viability of the cells, the cytotoxic effects of Lfs on the cells were investigated. PBMCs and HepG2 cells were treated with each protein at concentrations of 0.5 and $1.0 \mathrm{mg} / \mathrm{ml}$ for 4 days. Cell viability was compared with that of untreated PBMCs and HepG2 cells. The results showed that all used Lfs had no adverse effects on the viability of PBMCs at concentrations of 0.5 or $1.0 \mathrm{mg} / \mathrm{ml}$ after incubation for 4 days as shown in Table 1 . While in case of HepG2 cells, the viability was reduced to around $90 \%$ only after 4 days of incubation at concentrations of 0.5 or $1.0 \mathrm{mg} / \mathrm{ml}$ for all used Lfs as shown in Table 1.

\section{Inhibition Potential of hLf, cLf, bLf and sLf}

All the Lfs used were demonstrated ability to completely inhibit $\mathrm{HCV}$ particles entry into HepG2 cells at concentration of $1.0 \mathrm{mg} / \mathrm{ml}$. HepG2 cells $\left(10^{5}\right)$ were cultured in duplicate as described in materials and methods section. The cells were inoculated with $\mathrm{HCV}$ infected sera pretreated with each Lf alone at concentrations of $0.25,0.5$ and $1.0 \mathrm{mg} / \mathrm{ml}$ for $60 \mathrm{~min}$ and cultured for seven days. The

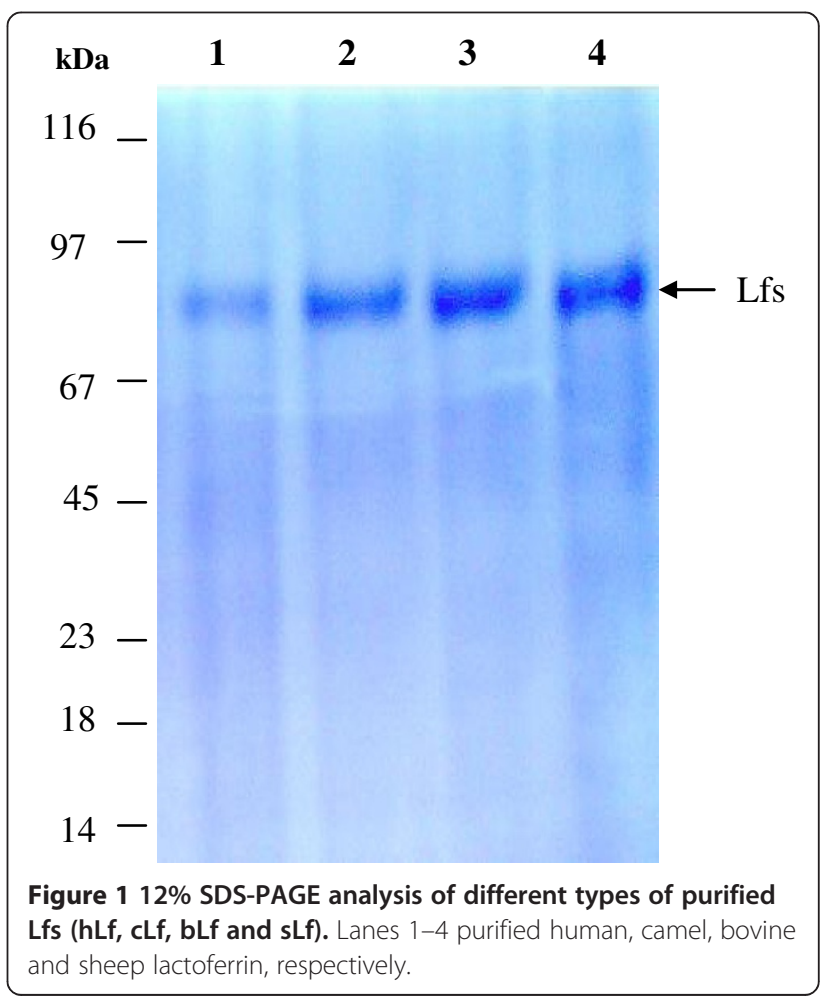


Table 1 Cell viability of lactoferrin forms by MTT method

\begin{tabular}{|c|c|c|c|c|}
\hline & \multicolumn{2}{|c|}{ HepG2 Cells } & \multicolumn{2}{|c|}{ PBMCs } \\
\hline & $0.5 \mathrm{mg} / \mathrm{ml}$ & $1.0 \mathrm{mg} / \mathrm{ml}$ & $0.5 \mathrm{mg} / \mathrm{ml}$ & $1.0 \mathrm{mg} / \mathrm{ml}$ \\
\hline Control & 100 & 100 & 100 & 100 \\
\hline Camel Lf & 92 & 89 & 100 & 100 \\
\hline Human Lf & 95 & 90 & 100 & 100 \\
\hline Bovine Lf & 94 & 88 & 100 & 100 \\
\hline Sheep Lf & 91 & 88 & 100 & 100 \\
\hline
\end{tabular}

RT-nested PCR amplified the $174 \mathrm{bp}$ region at the $5^{\prime}$ of $\mathrm{HCV}$ non coding sequence in comparison to the positive and negative control. The result revealed that the clf, was able to completely inhibit the HCV entry into HepG2 cells at concentrations of 0.5 and $1.0 \mathrm{mg} / \mathrm{ml}$. While the results showed that the hLf, bLf and sLf have a similar ability of
cLf to completely inhibit the HCV entry into cells at concentration of $1.0 \mathrm{mg} / \mathrm{ml}$ only, but at concentrations $0.25 \mathrm{mg} / \mathrm{ml}$ for all used Lfs were failed to prevent or block $\mathrm{HCV}$ particles from entry into HepG2 cells as shown in Figure 2.

\section{Effect of hLf, cLf, bLf and sLf on intracellular replication of $\mathrm{HCV}$ \\ Using RT-nested-PCR}

In order to determine the inhibitory effects of Lf on $\mathrm{HCV}$ replication in infected HepG2 cells, Lf treatment was performed at different concentrations. Results showed that cLf, hLf, bLf and sLf effectively inhibit HCV replication in infected HepG2 cells. hLf, bLf and sLf at concentrations of 0.25 and $0.5 \mathrm{mg} / \mathrm{ml}$ and cLf at concentrations of 100, 150, 200, 250 and $500 \mu \mathrm{g} / \mathrm{ml}$ were investigated for their in vitro

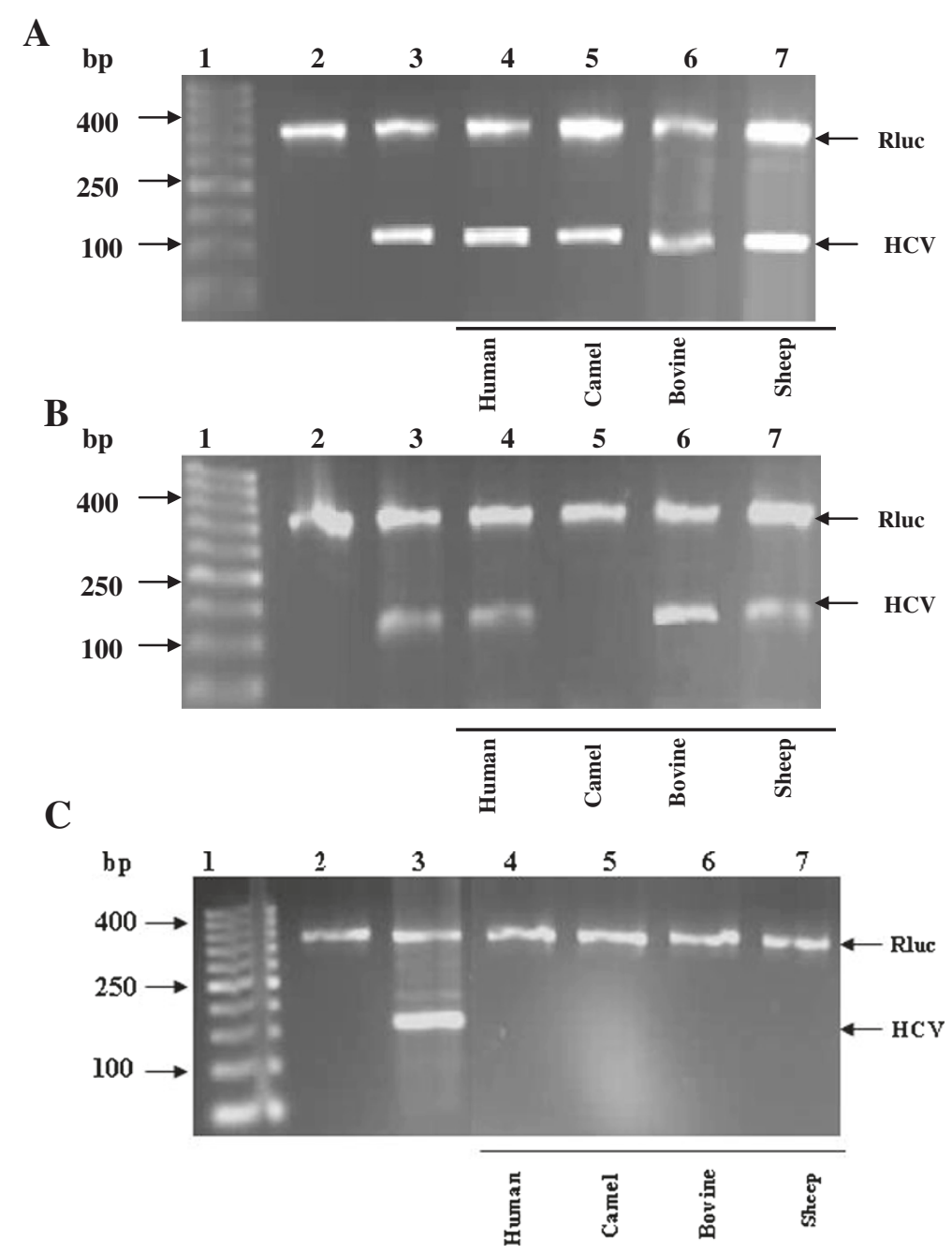

Figure 2 Prevention of HCV entry into HepG2 cells by different types of Lfs (hLf, bLf, cLf and sLf). Lane 1, DNA ladder; lane 2, negative control (HepG2 cells served as negative control); lane 3, positive control (infected HepG2 cells with HCV served as positive control); lanes 4-7, comparison among different Lfs at concentration of $0.25 \mathrm{mg} / \mathrm{ml}(\mathbf{A}), 0.5 \mathrm{mg} / \mathrm{ml}$ (B) and $1.0 \mathrm{mg} / \mathrm{ml}$ (C), as indicated under the gel graph. Rluc served as internal control. 
ability to inhibit the viral replication inside the infected HepG2 cells. Camel Lf has the ability to inhibit HCV replication at concentrations starts from 200, 250 and $500 \mu \mathrm{g} / \mathrm{ml}$ after four days of treatment, but cLf at concentrations of 100 and $150 \mu \mathrm{g} / \mathrm{ml}$ was failed to block the $\mathrm{HCV}$ replication inside the infected cells as shown in Figure 3. However, human, bovine and sheep Lfs were able to completely inhibit the replication of HCV at concentration starts from $0.5 \mathrm{mg} / \mathrm{ml}$, while at concentration of $0.25 \mathrm{mg} / \mathrm{ml}$, those proteins were failed to prevent $\mathrm{HCV}$ replication inside infected HepG2 cells as shown in Figure 4.

\section{Using real time PCR}

The results were indicated that the camel lactoferrin at all concentrations used was able to prevent HCV particles from replication inside HepG2 cells completely as shown in Table 2. The activity of bovine lactoferrin became $100 \%$ at concentration 0.5 and $0.75 \mathrm{mg} / \mathrm{ml}$ and drastically declined to become $7.28 \%$ at concentration of $0.25 \mathrm{mg} / \mathrm{ml}$. However, sheep Lf was able to complete inhibition of HCV replication inside infected HepG2 cells with relative activity $100 \%$ at concentrations of 0.5 and $0.75 \mathrm{mg} / \mathrm{ml}$ and the activity was decreased to become $16.73 \%$ at concentration of $0.25 \mathrm{mg} / \mathrm{ml}$ (Table 2). While the activity of human lactoferrin on HCV replication inside infected HepG2 cells decreased from 100\% at concentrations of 0.5 and $0.75 \mathrm{mg} / \mathrm{ml}$ to become $24.48 \%$ at concentration of $0.25 \mathrm{mg} / \mathrm{ml}$ as shown in Table 2 .

\section{Using flow cytometry}

The obtained results using flowcytometery were confirmative for the above results through evaluation of the effect of the lactoferrin forms on intracellular burden and may tracing the $\mathrm{HCV}$ by the indirect intracellular immunostaining of HCV antigens with the flowcytometry. Camel Lf could inhibit the replication of $\mathrm{HCV}$ at concentrations of 0.20 and $0.5 \mathrm{mg} / \mathrm{ml}$ after four days of treatment
(Figure 5). However, human, bovine and sheep Lfs were accomplished their $\mathrm{HCV}$ replication inhibition at $0.5 \mathrm{mg} /$ $\mathrm{ml}$ concentration as detected high fluorescence signal in FACS scan profile (Figure 5).

\section{Discussion}

Lactoferrin is an iron binding protein, which a member of the transferrin family present mainly in breast milk and in lower extent in bile, tears and in other exocrine secretions. However, Lf is also found in plasma derived from predominantly neutrophil secondary granules, release of which increases during inflammation. Breast milk contains several components with antimicrobial activity. The most one with antiviral activity detected in milk can be ascribed to Lf $[15,19,20]$. The antiviral activity of Lf is directed against a broad spectrum of viruses, including both RNA- and DNA-viruses. Because of the importance of HCV as a human pathogen and the lack of an effective treatment or protective vaccine [21,22], there is a crucial need to screening new compounds having anti-HCV activity with lower side effects. Previously we have shown that camel lactoferrin inhibits HCV genotype 4 from entry to PBMC, HepG2 and HepG2 cells and cLf has also been shown to inhibit the HCV G4 replication inside infected cells [12-15,20]. In the current study, we were tested and compared the inhibitory effect of hLf, bLf, cLf and sLf against HCV G4.

This is the first study showing that the entry of HCV G4 to HepG2 cells and the replication of the virus inside it are prevented by hLf, cLf, bLf and sLf. The results demonstrated that the cLf displayed its effective inhibition against $\mathrm{HCV}$ entry as well as replication in infected HepG2 cells more than hLf, bLf and sLf. Current study indicated that the cLf inhibit the HCV entry into HepG2 cells at concentrations of 0.5 and $1.0 \mathrm{mg} / \mathrm{ml}$, while hLf, bLf and sLf have the same ability of cLf to inhibit the HCV entry into cells but at concentration of $1.0 \mathrm{mg} / \mathrm{ml}$, whereas they were failed to inhibit the entry of the virus into cells at concentration of $0.25 \mathrm{mg} / \mathrm{ml}$. However, at all concentrations the

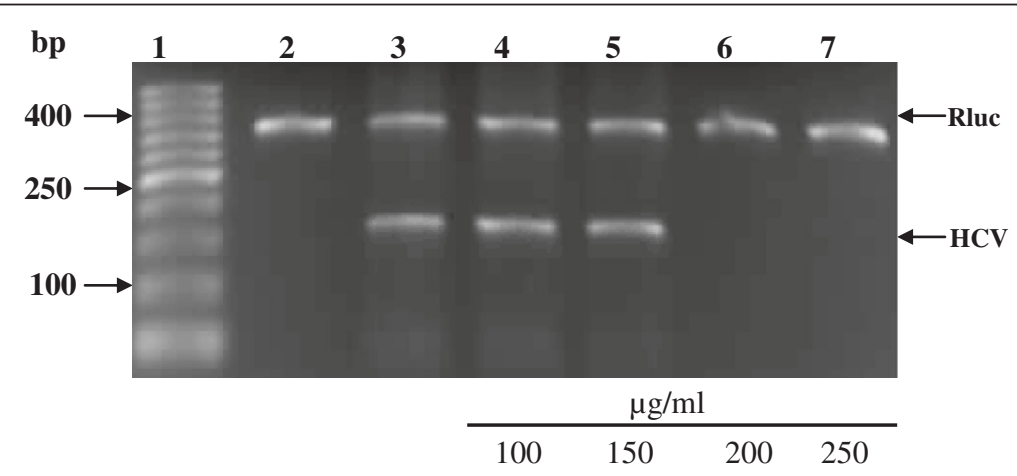

Figure 3 Inhibition of HCV amplification in infected HepG2 cells by camel lactoferrin at different concentrations. Lane 1, DNA ladder; lane 2, negative control (HepG2 cells served as negative control); lane 3, positive control (infected HepG2 cells with HCV served as positive control); lane 4-7, comparison among different concentrations of cLf. Rluc served as internal control. 


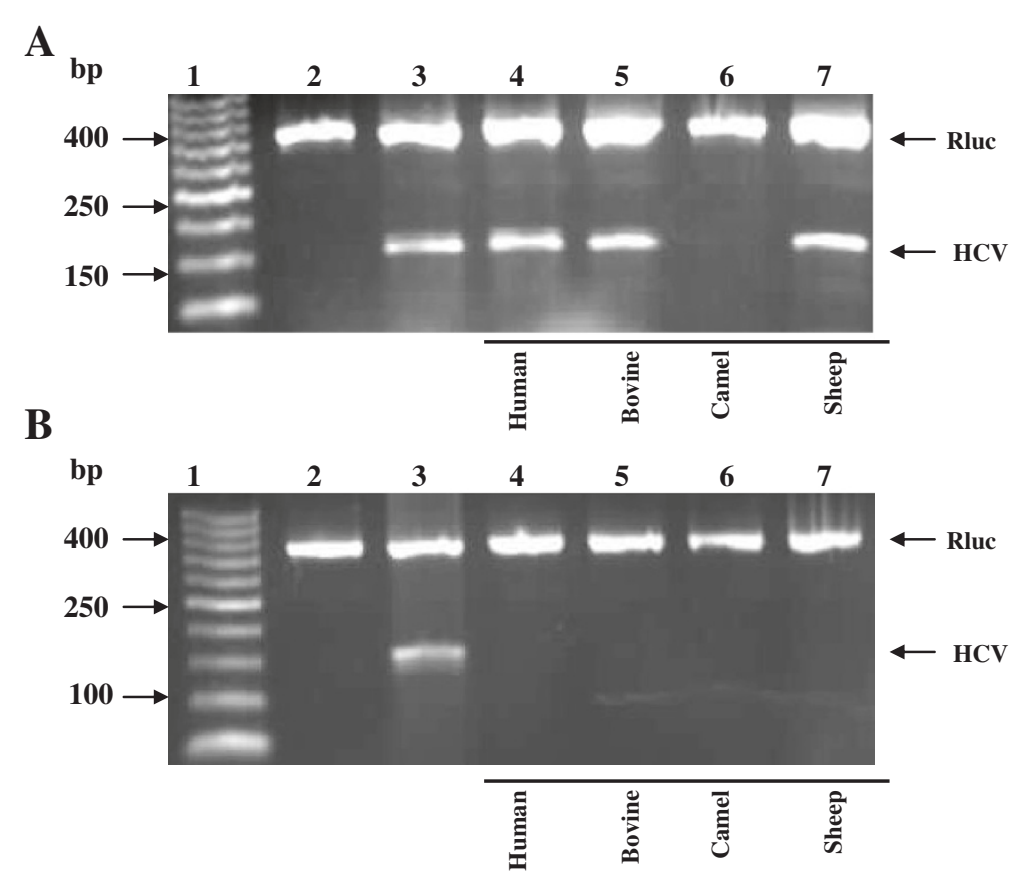

Figure 4 Inhibition of HCV amplification in infected HepG2 cells by different types of Lfs. Lane 1, DNA ladder; lane 2, negative control (HepG2 cells served as negative control); lane 3, positive control (infected HepG2 cells with HCV served as positive control); lane 4-7, comparison among different types of LFs at concentration of $0.25 \mathrm{mg} / \mathrm{ml}$ (A) and $0.5 \mathrm{mg} / \mathrm{ml}$ (B). Rluc served as internal control.

cLf was able to prevent HCV particles from replication inside the HepG2 cells, The activity of hLf decreased from $100 \%$ at concentrations of 0.5 and $0.75 \mathrm{mg} / \mathrm{ml}$ to became $24.48 \%$ at concentration of $0.25 \mathrm{mg} / \mathrm{ml}$, and bLf activity was decreased from $100 \%$ at concentration 0.5 and $0.75 \mathrm{mg} / \mathrm{ml}$ to became $7.28 \%$ at concentration of $0.25 \mathrm{mg} / \mathrm{ml}$. Whereas,

Table 2 Quantitation in vitro comparison among different types of LFs (human, bovine, camel and sheep) activity against HCV-infected HepG2 cells

\begin{tabular}{lccc}
\hline Protein & $\begin{array}{c}\text { Protein conc. } \\
\text { (mg/ml) }\end{array}$ & $\begin{array}{c}\text { Calc. conc. } \\
(\mathbf{I U / m l )}\end{array}$ & Relative activity (\%) \\
\hline control & Positive & 100410 & 0.0 \\
Human LF & Negative & 0.0 & 100 \\
& 0.25 & 75820 & 24.48 \\
Bovine LF & 0.5 & 0 & 100 \\
& 0.75 & 0 & 100 \\
& 0.25 & 93100 & 7.28 \\
Camel LF & 0.5 & 0 & 100 \\
& 0.75 & 0 & 100 \\
& 0.25 & 0 & 100 \\
Sheep LF & 0.5 & 0 & 100 \\
& 0.75 & 0 & 100 \\
& 0.25 & 83610 & 16.73 \\
& 0.5 & 0 & 100 \\
\hline
\end{tabular}

sLf was able to inhibit HCV replication inside infected cells with relative activity of $100 \%$ at concentrations of 0.5 and $0.75 \mathrm{mg} / \mathrm{ml}$ and its activity was $16.73 \%$ at concentration of $0.25 \mathrm{mg} / \mathrm{ml}$.

The HCV inhibition potential was simultaneously analyzed at viral RNA level (by RT-nested-PCR, real time PCR) and furthermore, using the highly sensitive intracellular staining for detection of the specific viral proteome. It seems that the flow cytomtery could exactly show the dose dependent decrease of the intracellular viral signals, and confirm the RNA viral load [23] through the ability to count the rate of infected cells directly. It precisely, when a typical forward and side scatter was classified to differentiate stained and non-stained cells or specific and non-specific immunofluorescence signals, was clear correlations between the flow cytometry and RT-PCR/real-time PCR. This approach appeared to be useful and dependable for anti-HCV agent discovery and/or their follow up $[12,24]$. Our findings are consistent with several previous studies, those using human and bovine lactoferrin to inhibit $\mathrm{HCV}$ (genotype1) entry into the $\mathrm{PH} 5 \mathrm{CH} 8$ cell-line $[25,26]$.

Many viruses are inhibited by Lf, which exhibits its antiviral activity at early stage of infection, most probably through preventing virus entry by interacting with the viral attachment receptor heparan sulfate $[17,18,27,28]$. However, the blocking of viral binding receptors on the cell surface cannot fully explain the antiviral activity of Lf 

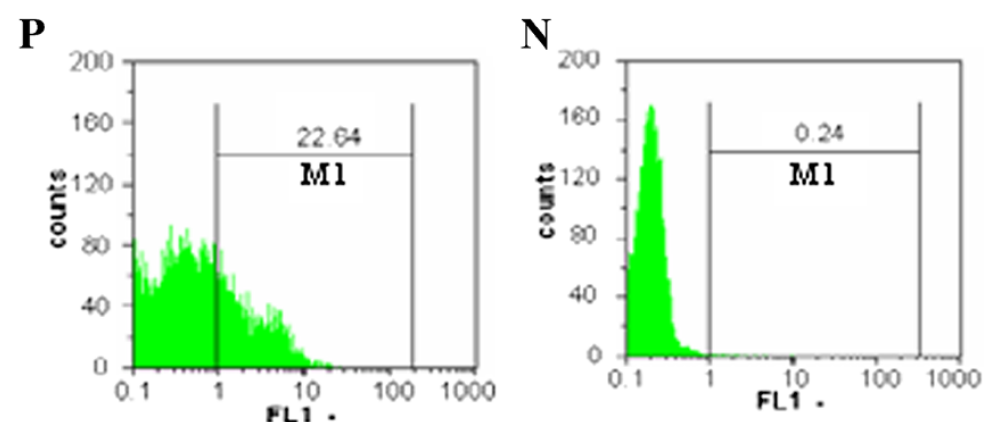

A1

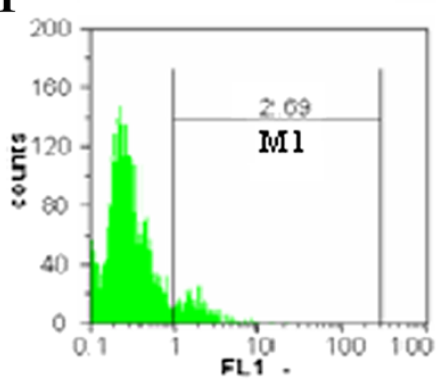

B1

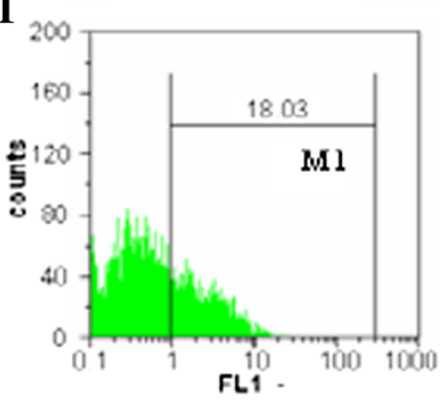

C1

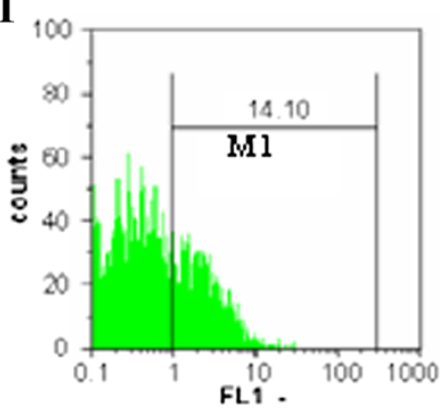

D1

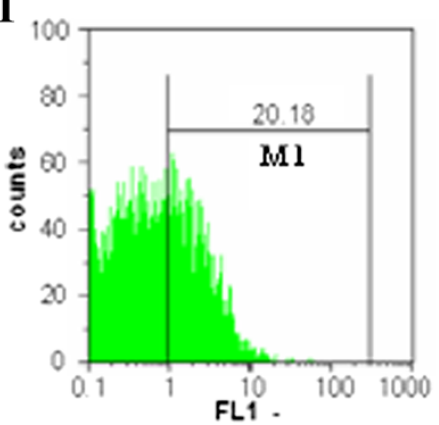

A2

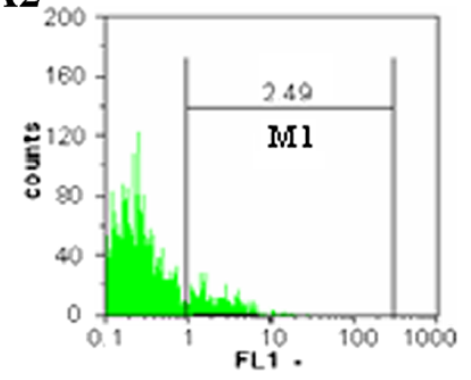

B2

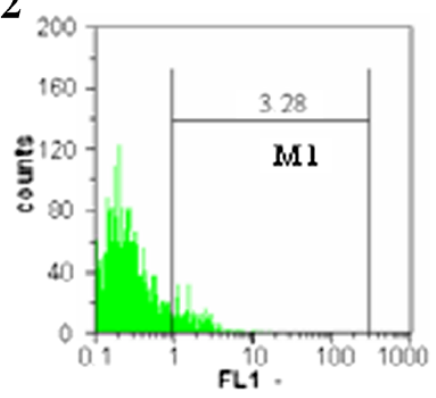

C2

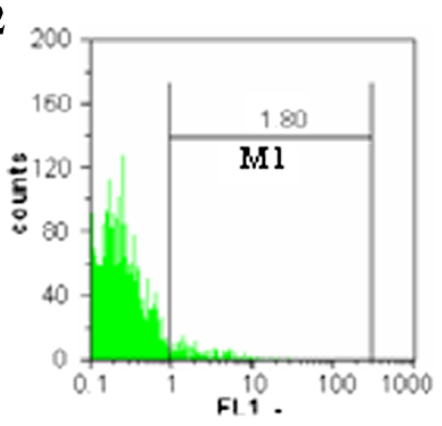

D2

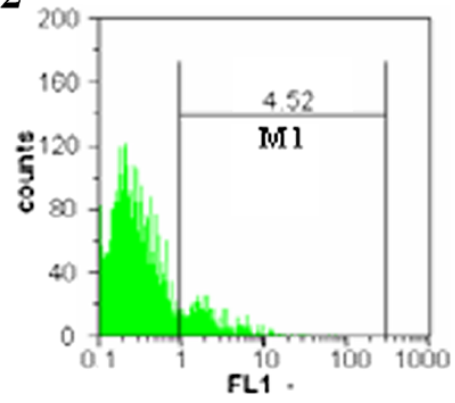

Figure 5 (See legend on next page.) 
[13,29]. Also many studies were analyzed the effect of Lf on picornavirus infection with different results. Marchetti et al. [30] demonstrated that bLf and hLf inhibited the early phases of poliovirus infection, whereas they were ineffective when added after the viral adsorption step. Successively, it was reported that hLf did not affect rhinovirus replication [31], while bLf exerted an inhibitory effect on enterovirus 71 attachment to target cells [32]. Camel Lf has three characteristics which make it unique over Lf of other species: 1) some critical residues such as Pro418, Leu423, Lys433, Gln651, Gly629, Lys637, Arg652, and Pro592 related to domain movement are different in cLf from those found in other Lf species, indicating of specific structural-related differences, 2) cLf loses $50 \%$ of its iron contents at pH 6.5 and the remaining $50 \%$ is lost at acidic condition ( $\mathrm{pH} 4.0-2.0)$. The N-lobe lost iron at acidic $\mathrm{pH}$ less than 4.0, whereas the C-lobe lost iron at $\mathrm{pH} 6.5$, which indicating a difference in the iron release mechanism from the two lobes, 3) the entirely difference in predicated glycosylation sites in cLf from other species. These data demonstrate that the cLf acts as half lactoferrin "iron binding protein" and half transferring "irontransporter protein", unlike other lactoferrins and transferrins [33]. A recent study showed that the therapy with bovine Lf lead to lipid peroxidation inhibition [34]. In accordance, the camel Lf maintains a dual function; 1) it inhibits lipid peroxidation and 2) it regulates the hepatic iron content through its ability to bind and transport the iron at acidic and basic pHs.

\section{Conclusions}

In Conclusion, we demonstrated, for the first time, that the camel lactoferrin has inhibitory activity on $\mathrm{HCV}$ (genotype 4a) double folds higher than human, bovine and sheep lactoferrin. However, the question still needs further analysis, why the camel lactoferrin has this superiority? Is it structure dependent, i.e. protein and/or carbohydrates wise?

\section{Materials and methods}

\section{Processing of milk and lactoferrin purification}

Milk from camels (Camelus dromedarius) was purchased from ALKHIR camel farm (Matrouh, Egypt) and transferred frozen to our laboratory, Bovine and sheep milk were purchase from local market and human was obtained from 10 healthy feeding mothers. A solution of sodium azide $(0.2 \%)$ containing $5 \mathrm{mM}$ EDTA and $5 \mathrm{mM}$ PMSF was added to the milk before defatting by centrifugation at $1000 \times \mathrm{g}$ for $30 \mathrm{~min}$ at $4^{\circ} \mathrm{C}$. The $\mathrm{pH}$ of skimmed milk was decreased to 4.2 with $1 \mathrm{M} \mathrm{HCl}$ to precipitate the casein $[13,20]$. Skimmed milk was used for Lf purification and diluted with $50 \mathrm{mM}$ Tris- $\mathrm{HCl}, \mathrm{pH} 8.0$ then samples containing $100 \mathrm{mg}$ protein was applied to Mono S 5/50 GL column $(5 \times 50 \mathrm{~mm}$, GE Health care, Sweden) previously equilibrated with $50 \mathrm{mM}$ tris $\mathrm{HCl}$, $\mathrm{pH} 8.0$ and column was washed with same equilibrated buffer to remove impurities. The elution was carried out with $50 \mathrm{mM}$ tris $\mathrm{HCl}, \mathrm{pH} 8.0$ and gradient from 0.0 to $1.0 \mathrm{M} \mathrm{NaCl}$ at flow rate of $1.0 \mathrm{ml} / \mathrm{min}$ and fraction size of $1.0 \mathrm{ml} /$ fraction using AKTA prime plus FPLC (GE Health care, Sweden). The fractions containing Lf were collected and concentrated by amicon ultrafiltration cell (Amicon 8200 Pmax 75 psi, $5.3 \mathrm{Kg} / \mathrm{cm} 2$ using $50 \mathrm{kDa}$ MWCO Amicon filter membrane (Millipore, Billerica, USA), then samples containing $0.8 \mathrm{mg}$ protein was applied to Superdex $2005 / 150$ column $(5 \times 150 \mathrm{~mm}$, GE Health care, Sweden) previously equilibrated with $50 \mathrm{mM}$ tris $\mathrm{HCl}$, $\mathrm{pH}$ 8.0. Elution of all Lfs was carried out with same equilibrated buffer at flow rate of $0.3 \mathrm{ml} / \mathrm{min}$ and fraction size of $0.5 \mathrm{ml} /$ fraction. The fractions containing Lf were concentrated by amicon ultrafiltration cell using $50 \mathrm{kDa}$ MWCO Amicon filter membrane (Millipore, Billerica, USA). The Lfs purity was confirmed by SDS-PAGE [35].

\section{Protein and endotoxin determination}

Protein was determined either by measuring the absorbance at $280 \mathrm{~nm}$ or by the method of Bradford [36] using bovine serum albumin as a standard protein. The endotoxin level of the purified lactoferrin was checked [37] to avoid its pyrogenic effects on the cell-culture system. All lactoferrin batches used were free of endotoxin (data not shown).

\section{Infected serum samples}

For all infection experiments, PCR-HCV positive serum samples of genotype 4 from Egyptian patient "A.R." (After approval from our Genetic Engineering and Biotechnology Research Institutes (GEBRI) institutes ethics committee) were used as previously described by Redwan and Tabll [12-15,38,39]. Written informed consent was obtained from the patient for the publication of this report and any accompanying images.

\section{Cytotoxic effect of lactoferrin forms}

The cytotoxicity of the purified Lfs on human separated PBMCs and HepG2 was examined by the 3-(4, 5dimethylthiazol-2-yl)-2, 5-diphenyltetrazolium bromide 
(MTT) test $[38,40,41]$. In brief, about $10^{4}$ PBMCs and HepG2 cells in $200 \mu$ l complete media were plated in 96well microtiter plates and cultured for overnight at $37^{\circ} \mathrm{C}$ before treatment with Lf forms, then the medium was refreshed with new DMEM supplemented medium containing $1.0 \mathrm{mg} / \mathrm{ml}$ or $0.5 \mathrm{mg} / \mathrm{ml}$ of protein. The cells were incubated for four days at $37^{\circ} \mathrm{C}$. After incubation, the cells were washed 3 times with PBS, and $200 \mu \mathrm{l}$ MTT solution $(0.5 \mathrm{mg} / \mathrm{ml}$ in PBS) was added to each well. After incubation for $3-5 \mathrm{~h}$ at $37^{\circ} \mathrm{C}, 5 \% \mathrm{CO} 2$, the medium was discarded and the wells were dried. Formazan crystals were resuspended in $200 \mu$ ldimethyl sulfoxide, followed by shaking for $5 \mathrm{~min}$ to thoroughly mix the formazan into the solvent. The optical density was read at $570 \mathrm{~nm}$. The relative cell viability (\%) compared to control wells containing cells without adding Lf was calculated using the following formula: (A) test/ (A) control $\times 100 \%$.

\section{In vitro comparison of neutralizing efficacy of different forms of lactoferrin Inhibition potential of the lactoferrin forms}

To examine the interaction of hLf, cLf, bLf and sLf with $\mathrm{HCV}, 1 \mathrm{ml}$ of infected serum and lactoferrin forms (final concentration at $0.25,0.5$ and $1.0 \mathrm{mg} / \mathrm{ml}$ ) was preincubated with DMEM media containing $2 \% \mathrm{HCV}$ infected serum for $1 \mathrm{~h}$ at $4^{\circ} \mathrm{C}$, and then the mixture of $\mathrm{HCV}$ and hLf, cLf, bLf or sLf was added to HepG2 $\left(1.0 \times 10^{5}\right)$ cells cultured in 24-well microtiter plate, and incubated for $90 \mathrm{~min}$ at $37^{\circ} \mathrm{C}, 5 \% \mathrm{CO} 2$ and $88 \%$ humidity. The cells were washed three times with $1 \mathrm{ml}$ of PBS and further incubated for 7 days at $37^{\circ} \mathrm{C}, 5 \% \mathrm{CO} 2$ and $88 \%$ humidity. (Positive HepG2 $\left(1.0 \times 10^{5}\right)$ cells were infected with HCV and negative HepG2 $\left(1.0 \times 10^{5}\right)$ cells only without infection) control cultures were included. The cells were washed three times from debris and dead cells by using DMEM supplemented media or $1 \times \mathrm{PBS}$, followed by total RNA extraction [12-15,38].

\section{Effect evaluation of the different lactoferrin on hepatitis C virus intracellular replication}

HepG2 cells were washed twice in DMEM supplemented media. The cells were suspended at $1.0 \times 10^{5}$ cells $/ \mathrm{ml}$ in DMEM culture media (DMEM supplemented media, 10\% fetal bovine serum (FBS); $100 \mathrm{U}$ of penicillin and $100 \mu \mathrm{g}$ streptomycin). The cells were left to adhere on 24-well plates for $24 \mathrm{~h}$ at $37^{\circ} \mathrm{C}, 5 \% \mathrm{CO} 2$ and $88 \%$ humidity, then infected with $\mathrm{HCV}$-infected serum in DMEM media and incubated for $24 \mathrm{~h}$ at $37^{\circ} \mathrm{C}, 5 \% \mathrm{CO} 2$ and $88 \%$ humidity. The purified cLf, was added at concentrations 100, 150, 200, 250 and $500 \mu \mathrm{g} / \mathrm{ml}$, while purified hLf, bLf and sLf were added at concentrations of 0.25 and $0.5 \mathrm{mg} / \mathrm{ml}$. Positive HepG2 $\left(1.0 \times 10^{5}\right)$ cells were infected with HCV and negative HepG2 $\left(1.0 \times 10^{5}\right)$ cells only without infection control cultures were included. The cells were incubated for four days at $37^{\circ} \mathrm{C}, 5 \% \mathrm{CO} 2$ and $88 \%$ humidity. After incubation the cells were washed three times from debris and dead cells by using DMEM supplemented media, then the cells were tested by RT-PCR and real time PCR.

\section{Isolation and extraction of RNA from HepG2 cells}

RNA was isolated from HepG2 cells as previously described [14]. Briefly, cells were precipitated by centrifugation at $1200 \mathrm{rpm}$ for $5 \mathrm{~min}$ at $4^{\circ} \mathrm{C}$ and washed three times with PBS or basal media to remove adherent viral particles before lysis in $4 \mathrm{~mol} / \mathrm{l}$ guanidine isothiocyanate containing $25 \mathrm{mM}$ sodium citrate, $0.5 \%$ sarcosyl and $100 \mathrm{mM} \beta$ mercaptoethanol and $100 \mu \mathrm{l}$ sodium acetate. The lysed cells were centrifuged at $12000 \mathrm{rpm}$ for $10 \mathrm{~min}$ at $4^{\circ} \mathrm{C}$. The aqueous layer was collected and mixed with equal volume of isopropanol. After incubation at $-20^{\circ} \mathrm{C}$ overnight, RNA was precipitated by centrifugation at $12000 \mathrm{rpm}$ for $20 \mathrm{~min}$ at $4{ }^{\circ} \mathrm{C}$ and the precipitate RNA was washed twice with $70 \%$ ethanol.

\section{RT-nested-PCR of HCV RNA}

Reverse transcription-nested PCR was carried out previously reported [12-15,38,42]. The complimentary DNA (cDNA) and the first PCR reaction of the nested PCR detection system for the HCV RNA was performed in a $50 \mu \mathrm{l}$ volume single-step reaction using the Ready-To-Go RTPCR beads (Amersham Pharmacia Biotech, Pis-cataway, NJ, USA), $400 \mathrm{ng}$ of total HepG2 cells RNA, $10 \mu \mathrm{M}$ of the reverse primer $1 \mathrm{CH}$ (for plus strand), $10 \mu \mathrm{M}$ of the forward primer $2 \mathrm{CH}$ (for minus strand) and $10 \mu \mathrm{M}$ of reverse primer P2. The test was incubated at $42^{\circ} \mathrm{C}$ for $30 \mathrm{~min}$ and denatured at $98^{\circ} \mathrm{C}$ for $10 \mathrm{~min}$. Amplification of the highly conserved 5 '-UTR sequences was done using two rounds of PCR with two pairs of nested primers (Clontech, USA). First round amplification was done in $50 \mu \mathrm{l}$ reaction mixture, containing $10 \mu \mathrm{M}$ from each of $2 \mathrm{CH}$ forward primer and P2 reverse primer, $0.2 \mathrm{mmol} / \mathrm{l}$ from each dNTP, $5 \mu \mathrm{l}$ from RT reaction mixture as template and $2 \mathrm{U}$ of Taq DNA polymerase (Promega, Madison, USA) in a $1 \times$ buffer supplied with the enzyme. The thermal cycling protocol was as follows: $1 \mathrm{~min}$ at $94^{\circ} \mathrm{C}, 1 \mathrm{~min}$ at $55^{\circ} \mathrm{C}$ and $1 \mathrm{~min}$ at $72^{\circ} \mathrm{C}$ for 30 cycles. The second round amplification was done similar to the first round, except for use of the nested reverse primer D2 and forward primer F2 at $10 \mu \mathrm{M}$ each. A fragment of $174 \mathrm{bp}$ was identified in positive samples. Primer sequences were as follows: $1 \mathrm{CH}$ : $5^{\prime}$-GGTGCACGGTC TACGAGACCTC-3', 2CH: 5'-AACTACTGTCTTCACG CAGAA-3', P2: 5'-TGCTCATGGTGCACGGTCTA-3', D2: 5' - ACTCGGCTAGCAGTCTCGCG-3' and F2: 5'-G TGCAG CCTCCAGGACCC-3'. To control false detection of negative-strand HCV RNA and known variations in PCR efficiency, specific control assays and rigorous standardization of the reaction were employed. The amplification process was included a Rulc plasmid as internal 
control, so the final amplified DNA were electrophoresed through 3\% agarose gel and ethidium bromide was used to visualized $174 \mathrm{bp}$ for $\mathrm{HCV}$ and $374 \mathrm{bp}$ of Rluc.

\section{Real time PCR to evaluation of antiviral activity of the clf, recombinant clf, $\mathrm{N}$-lobe, recombinant $\mathrm{N}$-lobe and $\mathrm{C}$-lobe against HCV}

We used real time PCR to examine the ability of hLf, clf, bLf and sLf at concentrations of $0.25,0.5$ and $0.75 \mathrm{mg} / \mathrm{ml}$ to prevent replication of $\mathrm{HCV}$ particles inside HepG2 cells. Briefly, infected HepG2 cells with HCV were treated with those proteins and cultured as described above. After incubation of HepG2 cells at suitable time the cells were washed three times from debris and dead cells by using PBS then HCV RNA was isolated and extracted from HepG2 cells by INSTANT Virus RNA Kit (AJ Roboscreen $\mathrm{GmbH}$ ). Amplification of HCV RNA in samples and standards is measured by RoboGene HCV RNA Quantification Kit (AJ Roboscreen $\mathrm{GmbH}$ ) use Rotor-Gene real time PCR machine (Corbett life Science, QIAGEN Company, model number R0708103) and report generated by RotorGene Q Series Software 1.7 (Build 94) Copyright 2008 Corbett Life Science, a QIAGEN Company.

\section{Detection of intracellular HCV by flow cytometry}

In this test Flow cytometry was used to evaluate the antiviral activity of the purified proteins (hLf, cLf, bLf and sLf). The HepG2 cells were suspended at $1.0 \times 10^{5}$ cells/ $\mathrm{ml}$ in DMEM culture media. The cells were infected with $\mathrm{HCV}$-infected serum and incubated for $24 \mathrm{~h}$ at $37^{\circ} \mathrm{C}, 5 \%$ $\mathrm{CO} 2$ and $88 \%$ humidity. The purified $\mathrm{Lf}$ forms were added at concentrations of 0.25 and $0.5 \mathrm{mg} / \mathrm{ml}$. Positive HepG2 $\left(1.0 \times 10^{5}\right)$ cells were infected with $\mathrm{HCV}$ and negative HepG2 $\left(1.0 \times 10^{5}\right)$ cells only without infection control cultures were included. The cells were incubated for four days at $37^{\circ} \mathrm{C}, 5 \% \mathrm{CO} 2$ and $88 \%$ humidity. The cells were washed three times from debris and dead cells by using $1.0 \times$ PBS. Intracellular labeling was performed by indirect immunofluorescence. Cells were centrifuged and supernatants were removed. Cell pellets were washed twice with $1.0 \times$ PBS containing $1 \%$ normal goat serum $(2 \%$ bovine serum albumin), cells were incubated with $4 \%$ paraformaldehyde for $10 \mathrm{~min}$ and $0.1 \%$ Triton X-100 in Tris buffer (pH 7.4) for 6 min. After washing three times with $1.0 \times$ PBS, the cells were incubated with monoclonal antibody against HCV core $(1: 1,000)$ was added to the cell suspension and incubated at room temperature for $1 \mathrm{~h}$ $[14,15,39]$. Then, the cells were washed three times with $1.0 \times$ PBS and the cells were immunofluorescence stained with fluorescein-conjugated goat anti-mouse and incubated at $4^{\circ} \mathrm{C}$ for $30 \mathrm{~min}$. After being washed, the cells were suspended in $2 \mathrm{ml}$ PBS and analyzed by Flow cytometry (Partic, Germany) [12,24].

\section{Statistical analysis}

Most measurements were repeated three times and the results are presented as the mean plus standard deviation. Data were analyzed by using Student's t-test.

\section{Abbreviations}

HCV: Hepatitis C Virus; HBV: Hepatitis B Virus; HIV: Human Immunodeficiency Virus; HSV: Herpes Simplex Virus; PBMCs: Peripheral blood monocyte cells; RTPCR: Reverse transcriptase-polymerase chain reaction; BSA: Bovine serum albumin; Lf: Lactoferrin; bLf: Bovine lactoferrin; CLf: Camel lactoferrin; hLf: Human lactoferrin; Lfs: Lactoferrins; PBS: phosphate buffer saline; MTT: Thiazolyl blue tetrazolium bromide; DMEM: Dulbecco's modefied eagle Medium; SDS-PAGE: Sodium dodecyl sulfate polyacrylamide gel; SEM: Standard Error of the mean.

\section{Competing interests}

Authors declare that they have no competing interest.

\section{Authors' contributions}

EME, performed tissue culture, viral screening research, protein purifications and all immunoassays and wrote the draft of manuscript; LS, help in data organization, data analysis, manuscript revision; HAA, contributed new reagents/analytical tools and contributed in MS writing; and EMR, design research, data management, manuscript finalizing in its final form. All the authors read and approved the final manuscript.

\section{Acknowledgement}

The study was funded by Egyptian-Spanish joint fund (AECl-A/024874/09) for EMR and partially by Science and Technology Development Fund (STDF-ID409).

\section{Author details}

'Therapeutic and Protective Protein Laboratory, Protein Research Department, Genetic Engineering and Biotechnology Research Institute, City for Scientific Research and Technology Applications, New Borg EL-Arab, Alexandria 21394, Egypt. ${ }^{2}$ Tecnología de los Alimentos, Facultad de Veterinaria, Universidad de Zaragoza, Miguel Servet 177, Zaragoza 50013, Spain. ${ }^{3}$ Biological Sciences Department, Faculty of Science, King Abdulaziz University, P.O. Box 80203, Jeddah 21589, Kingdom of Saudi Arabia.

Received: 12 April 2013 Accepted: 6 June 2013

Published: 19 June 2013

\section{References}

1. Williams R: Global challenges in liver disease. Hepatology 2006, 44:521-526.

2. Nguyen $\mathrm{MH}$, Keeffe EB: Prevalence and treatment of hepatitis $\mathrm{C}$ virus genotypes 4, 5, and 6. Clin Gastroenterol Hepatol 2005, 3:S97-S101.

3. Abdel-Aziz F, Habib M, Mohamed MK, Abdel-Hamid M, Gamil F, Madkour S: Hepatitis $\mathrm{C}$ virus (HCV) infection in a community in the Nile Delta: population description and HCV prevalence. Hepatology 2000, 32:111-115.

4. Elkady A, Tanaka Y, Kurbanov F, Sugauchi F, Sugiyama M, Khan A: Genetic variability of hepatitis $C$ virus in South Egypt and its possible clinical implication. J Med Virol 2009, 81:1015-1023.

5. Deuffic-Burban S, Poynard T, Sulkowski MS, Wong JB: Estimating the future health burden of chronic hepatitis $C$ and human immunodeficiency virus infections in the United States. J Viral Hepatol 2007, 14:107-115.

6. Legrand D, Pierce A, Elass E, Carpentier M, Mariller C, Mazurier J: Lactoferrin structure and functions. Adv Exp Med Biol 2008, 606:163-194.

7. Legrand D, Elass E, Carpentier M, Mazurier J: Lactoferrin: a modulator of immune and inflammatory responses. Cell Mol Life Sci 2005, 62:2549-2559.

8. Marchetti M, Pisani S, Antonini G, Valenti P, Seganti L, Orsi N: Metal complexes of bovine lactoferrin inhibit in vitro replication of herpes simplex virus type 1 and 2. BioMetals 1998, 11:89-94.

9. Valenti P, Marchetti M, Superti F, Amendolia MG, Puddu P, Gessani S, Borghi $P$, Belardelli F, Antonini G, Seganti SL: Antiviral activity of lactoferrin. Adv Exp Med Biol 1998, 443:199-203.

10. Ikeda M, Sugiyama K, Tanaka T, Tanaka K, Sekihara H, Shimotohno K, Kato N: Lactoferrin markedly inhibits hepatitis $\mathrm{C}$ virus infection in cultured human hepatocytes. Biochem Biophys Res Commun 1998, 245:549-553.

11. Yi M, Kaneko S, Yu DY, Murakami S: Hepatitis C virus envelope proteins bind lactoferrin. J Virol 1997, 71:5997-6002. 
12. Redwan $\mathrm{EM}$, Tabll A: Camel lactoferrin markedly inhibits hepatitis $\mathrm{C}$ virus genotype 4 infection of human peripheral blood leukocytes. J Immunoassay Immunochem 2007, 28:267-277.

13. EL-Fakharany EM, Tab\|l A, Redwan EM: Potential activity of camel milkamylase and lactoferrin against hepatitis c virus infectivity in HepG2 and lymphocytes. Hepat Mon 2008, 8:101-109.

14. Liao Y, El-Fakkarany E, Lönnerdal B, Redwan EM: Inhibitory Effects of Native/ Recombinant Full-Length Camel Lactoferrin and its N/C lobes on Hepatitis C Virus Infection of Huh7.5 Cells. J Med Microbio/ 2012, 61:375-383.

15. EL-Fakharany EM, El-baky NA, Haroun BM, Sánchez L, Redwan NA, Redwan EM: Anti-infectivity of camel polyclonal antibodies against hepatitis C virus in Huh7.5 hepatoma. J Virol 2012, 9(201):1-9.

16. Jenssen H, Andersen JH, Uhlin-Hansen L, Gutteberg TJ, Rekdal O: Anti-HSV activity of lactoferricin analogues is only partly related to their affi nity for heparan sulfate. Antiviral Res 2004, 61:101-109.

17. Andersen JH, Jenssen H, Sandvik K, Gutteberg TJ: Anti-HSV activity of lactoferrin and lactoferricin is dependent on the presence of heparin sulphate at the cell surface. J Med Virol 2004, 74(2):262-271.

18. Marchetti M, Trybala E, Superti F, Johansson M, Bergstöm T: Inhibition of herpes simplex virus infection by lactoferrin is dependent on interference with the virus binding to glycosaminoglycans. Virology 2004, 318:405-413.

19. van der Strate BWA, Beljaars L, Molena G, Harmsen MC, Meijer DKF: Antiviral activities of lactoferrin. Antiviral Res 2001, 52:225-239.

20. Almahdy O, EL-Fakharany EM, EL-Dabaa E, Ng TB, Redwan EM: Examination of the Activity of Camel Milk Casein against Hepatitis C Virus (Genotype4a) and Its Apoptotic Potential in Hepatoma and HeLa Cell Lines. Hepas Mon 2011, 11:724-730.

21. Redwan EM: Cumulative updating of approved biopharmaceuticals. Hum Antibodies 2007, 16:137-158.

22. Redwan EM: Animal-derived pharmaceutical proteins. J Immunoassay Immunochem 2009, 30:262-290.

23. Yang JH, Lai JP, Douglas SD, Metzger D, Zhu X, Ho W: Real-time RT-PCR for quantitation of hepatitis C virus RNA. J Virol Meth 2002, 102:119-128.

24. EL-Awady MK, Tabll AA, Redwan EM, Youssef S, Omran MH, El-Demellawy M: Flow cytometric detection of hepatitis $C$ virus antigens in infected pripheral blood leukocytes: binding and entry. W J Gastroenterol 2005, 11:5203-5208

25. Ikeda M, Nozaki A, Sugiyama K, Tanaka T, Naganuma A, Tanaka K, Sekihara H, Shimotohno K, Saito M, Kato N: Characterization of antiviral activity of lactoferrin against hepatitis $C$ virus infection in human cultured cells. Virus Res 2000, 66:51-63.

26. Nozaki A, Ikeda M, Naganuma A, Nakamura T, Inudoh M, Tanaka K, Kato N: Identification of a lactoferrin-derived peptide possessing binding activity to hepatitis C virus E2 envelope protein. J Biol Chem 2003, 278:10162-10173.

27. Drobni $\mathrm{P}$, Naslund J, Evander M: Lactoferrin inhibits human papillomavirus binding and uptake in vitro. Antiviral Res 2004, 64(1):63-68

28. Hara K, Ikeda M, Saito S, Matsumoto S, Numata K, Kato N, Tanaka K, Sekihara $\mathrm{H}$ : Lactoferrin inhibits hepatitis B virus infection in cultured human hepatocytes. Hepatol Res 2002, 4(3):228-235.

29. Seganti L, Di Biase AM, Rega B, De Giulio B, Nicoletti M, Antonini G, Valenti $P$ : Involvement of bovine lactoferrin moieties in the inhibition of herpes simplex virus type 1 infection. Int J Immunopathol Pharmacol 2001 14(2):71-79.

30. Marchetti M, Superti F, Ammendolia MG, Rossi P, Valenti P, Seganti L: Inhibition of poliovirus type 1 infection by iron-, manganeseand zincsaturated lactoferrin. Med Microbiol Immunol 1999, 187:199-204.

31. Clarke NM, May JT: Effect of antimicrobial factors in human milk on rhinoviruses and milk-borne cytomegalovirus in vitro. J Med Microbiol 2000, 49:719-723.

32. Lin TY, Chu C, Chiu CH: Lactoferrin inhibits enterovirus 71 infection of human embryonal rhabdomyosarcoma cells in vitro. J Infect Dis 2002, 186:1161-1164

33. Khan JA, Kumar P, Paramasivam M, Yadav RS, Sahani MS, Sharma S: Camel lactoferrin, a transferrin-cumlactoferrin: crystal structure of camel apolactoferrin at $2.6 \AA$ resolution and structural basis of its dual role. J Mol Biol 2001, 309:751-761.

34. Konishi M, Iwasa M, Yamauchi K, Sugimoto R, Fujita N, Kobayashi Y: Lactoferrin inhibits lipid peroxidation in patients with chronic hepatitis C. Hepatol Res 2006, 36:27-32.
35. Laemmli UK: Cleavage of structural proteins during the assembly of the head of bacteriophage T4. Nature 1970, 227:680-685.

36. Bradford MM: A rapid sensitive method for the quantitation of microgram quantities of protein utilizing the principle of protein-dye binding. J Anal Biochem 1976, 72:248-254

37. Redwan E: Simple, sensitive and quick protocol to detect less than 1ng of bacterial lipopolysaccharide. Prep Biochem Biotechnol 2012, 42:1-12.

38. El-Fakharany EM, Haroun BM, Ng TB, Redwan ER: Oyster Mushroom Laccase Inhibits Hepatitis C Virus Entry into Peripheral Blood Cells and Hepatoma Cells. Protein Pept Lett 2010, 17(8):1031-1039.

39. EL-Baky NA, Omar SH, EL-Badry H, Redwan EM: Efficacy comparison of gel-based, membrane and glass array techniques to detect human antibodies isotypes among the Egyptian HCV-patients. Hum Antibodies 2008, 17:63-71.

40. Mosmann T: Rapid colorimetric assay for cellular growth and survival: Application to proliferation and cytotoxicity assays. $J$ Immunol Methods 1983, 65(1-2):55-63.

41. El-Baky NA, Omar SH, Redwan EM: The anti-cancer activity of human consensus interferon-alpha synthesized in cell-free system. Protein Express Purif 2011, 80:61-67.

42. EL-Awady MK, Tabll AA, El-Abd YS, Bahgat MM, Shoeb HA, Youssef SS, Be-D NG, Redwan E-RM, El-Demellawy M, Omran MH, El-Garf WT, Goueli SA: HepG2 cells support viral replication and gene expression of hepatitis $C$ virus genotype 4 in vitro. W J Gastroenterol 2006, 12:4836-4842.

doi:10.1186/1743-422X-10-199

Cite this article as: EL-Fakharany et al:: Effectiveness of human, camel, bovine and sheep lactoferrin on the hepatitis $C$ virus cellular infectivity: comparison study. Virology Journal 2013 10:199.

\section{Submit your next manuscript to BioMed Central and take full advantage of:}

- Convenient online submission

- Thorough peer review

- No space constraints or color figure charges

- Immediate publication on acceptance

- Inclusion in PubMed, CAS, Scopus and Google Scholar

- Research which is freely available for redistribution

Submit your manuscript at www.biomedcentral.com/submit
C Biomed Central 